\title{
'The Shape of Things to Come': Seven Theses on the Anthropocene and Attachment
}

\author{
Ben Dibley
}

\section{I.}

Anthropocene as epoch and as discourse: As epoch and as discourse it would seem the Anthropocene has arrived. For it is a term that supplies an arresting image of a daunting development: the advent of a geological era of humanity's own making. For the earth system scientists who have championed the notion, the Anthropocene signals a geological interval since the industrial revolution, where, through its activities, through its numbers, the human species has emerged as a geological force now altering the planet's biosphere. Because of these developments the relatively benign planetary conditions of the Holocene - the previous 12,000 years, which enabled the establishment of agriculture and the rise of urban civilizations - are in the process of transformation.

The exponential growth in the human population and the associated resource intensive practices on which this is contingent have produced various stratigraphical signals. For earth system scientists the most obvious of these sedimentary layers is Anthropocene rock - the concrete, steel and bitumen of the planet's cities and roads (Zalasiewicz et al., 'New World'); while the most enduring are anthropogenic biochemical processes - emission of greenhouse gases, acidification of the oceans, modification of soils, destruction of biota and relocation of genetic stocks and increasingly codes. All of these are now in the process of permanently altering the earth's systems and the evolutionary trajectory of planetary life (Zalasiewicz et al. 'Are We Now?'; Steffen et al.). For the term's advocates it is the emergence of the human species as this geological forcing agent that signals the close of the Holocene and the opening of a new epoch.

The notion of the Anthropocene, then, vividly captures the folding of the human into the air, into the sea, the soil and DNA. ${ }^{1}$ As a force imperilling 'the

1 Here then, the notion of the Anthropocene might be seen as an implicit criticism of the hegemony of the climate crisis at the level of public discourse - in as much as the latter, in its staging in policy and popular imaginaries and, indeed, those of humanities and social science scholars, frequently neglects the couplings of the earth's systems. In this, the Anthropocene serves as a reminder that the resolution of the climate crisis will 
safe operating space for humanity with respect to the earth system', it is an emergence that is simultaneously an emergency (Rockström et al. 475). ${ }^{2}$ As a pithy appellation the Anthropocene is a term increasingly entering public and policy discourses, and indeed, the lexicon of the humanities and social sciences. ${ }^{3}$

\section{II.}

The Anthropocene is the crease of time: The Anthropocene is the appellation for the folding of radically different temporal scales: the deep time of geology and a rather shorter history of capital. The advent of the human as a geological agent demands ways of thinking these temporalities together. If, until relatively recently, earth scientists considered humans too new and too insignificant to impact on geological processes, social scientists and humanities scholars have long viewed the geological as far too slow moving to influence social transformations; particularly those over the last 400 years or so that concern students of modernity. When the geologic registers in the latter archive, it is as an inexplicable, violent intrusion into life. Famously, for example, the 1755 Lisbon earthquake solicited profound theological and philosophical investigations; more recently events such as the Asian Tsunami and Hurricane Katrina have prompted important insights into the social construction of disaster and its ensuing tragedy. In these treatises on corporeal frailty and moral culpability, the natural cataclysm is an episodic irruption into life that reveals its follies. The physical phenomenon itself is but a devastating glitch in an otherwise stable natural backdrop. In collision, then, the human and the geological remain separate entities.

However, it is clear that the emergence of the Anthropocene makes this assumption separating geological time and human time untenable. This of course is not to assert an anthropological dimension to the manifestation of earthquakes and

not in itself witness the return to ecological 'safety', which, however difficult to realise, would seem to be the implicit assumption of much public discourse on that crisis; cf., for example, the 'back to the safety of 350 parts per million' that is the signature of Bill McKibben's 350.org campaign. This is not to imply the existence of a ready solution to that crisis. As Mike Hulme (Why We Disagree) among other climatologists makes clear, the climate cannot be 'fixed' in any straightforward sense. However, what the notion of the Anthropocene does demonstrate is that the human is entangled in earth system processes in ways whose complexity cannot be reduced to those of climate change alone. For climate is only one of a cohort of 'planetary boundaries' whose thresholds are complexly entangled and whose 'delicate balance' must be maintained to secure a Holocene-like state (Rockström et al., 461).

2 On the emergence of life as emergency see Dillon and Lobo-Guerrero.

3 For some examples limited to those that include the term in their titles see Boykoff; Dalby; Gibson-Graham and Roelvink; Hodson and Marvin; Lövbrand et al.; Rigby; Robin and Steffen; Shellenberger and Nordhaus. What is striking in the term's migration into the discourses of the humanities and social sciences is that it has occasioned little critical reflection on the notion itself. However, see Lövbrand et al. and Crist. These two papers take positions respectively informed by governmentality theory and critical theory. 
tsunamis; ${ }^{4}$ rather, it is to say that in an era of global anthropogenic environmental change an adequate investigation of contemporary social formations necessarily demands the simultaneous conceptualization of temporal scales that once appeared incommensurable. ${ }^{5}$

In his 'Theses on the Philosophy of History', Walter Benjamin quotes an unnamed biologist who arrestingly captures the brevity of human existence on the planet: 'In relation to organic life on earth ... the paltry fifty millennia of homo sapiens constitute something like two seconds at the close of a twentyfour hour day. On this scale the history of civilized mankind would fill one-fifth of the last second of the last hour' (263). Read against the grain of Benjamin's dialectical image and its truncation into Messianic time, the point would now be to see these closing split seconds as the increasingly critical ones where the particular antagonisms of capital unleash the potentiality to alter the trajectory of geological processes, and with it, the universal: life on earth. ${ }^{6}$ The significance of the Anthropocene in this sense is in naming this folding of geological time and the time of capital.

\section{III.}

The Anthropocene opposes freedom: In its classical formulations political modernity is posed as the struggle for emancipation-as the escape from the shackles of nature, of tradition, of exploitation that foreclose on human dignity and liberty. It is a project that, historically, whether in its capitalist or socialist formulations, has been dependent on the massive appropriation of the Earth's resources in its promise of the expansion of human freedom (as it is variously conceived). But it is a project whose externalities, as the economists would say, or in the parlance of the sociologists, its global risks, now radically put into question the assumptions on which such formulations rest; for the unintended consequences of modernity's emancipatory quest now threaten with destruction its very life support system: the biosphere.

In one sense then the Anthropocene is a counter-discourse to globalization - a narrative of its externalities, its risks, its unintended consequences, its limits which now require calibration to identify 'planetary boundaries' that global modernity must not transgress if the safety of a Holocene-like condition is to be preserved (Rockström et al.). In another sense it is also a discourse, which - in its imbrications in proposals from technological fixes to global governance - is inescapably entangled in notions of reason and liberty inherited

4 However, there is evidence that recent volcanic activity such as that of Eyjafjallajökull in October 2010 have an anthropogenic dimension due to thinning of the arctic ice caps (see Sigmundsson et al.).

5 See Chakrabarty, 'Brute Force'; 'Climate of History'.

6 See Žižek's (Living 330-337) objections to Chakrabarty's ('Climate of History') theses. 
from modernity's project. This is so inasmuch as that task is one of securing the conditions whereby, as the notion's interlocutors put it, 'humanity has the freedom to pursue long-term social and economic development' (Rockström et al.). This is a security contingent on a metrology of the Earth system that prepares it for the market, coding it as so many ecological stocks, services and sinks. This, at least, appears to be the predominant mechanism through which liberty in the Anthropocene will come to be ruled.

On the one hand then, what the Anthropocene poses as an epoch is not only potential tipping points in planetary biogeochemical processes which imperil the human species' life-support system; it is also the antithesis of a politicoontological condition central to modernity: freedom. That is, as an autonomous object of knowledge, the Anthropocene posits absolute limits to human activity, curtailing the sphere of human freedom. On the other hand, as a field of intervention, the parametric boundaries necessary to maintain a Holocene-like state are ones that are to be secured through market mechanisms. That is, as the target of policy discourse, the Anthropocene is a condition to be governed through freedom's rule. For it is hoped that through such rule the planetary parametric boundaries will be secured, and with it the sphere of human freedom. This, at least, is the gamble of green capitalism. ${ }^{7}$

\section{IV.}

The Anthropocene - nostalgia for the human: The Anthropocene is an ambivalent formulation. It at once announces a new epoch and a new geological agent which would make any distinction between nature and society untenable; and yet it also retains nostalgia for that very distinction. Through technology, science and markets, the species-life of humans is now so entangled with the planet's biogeochemical systems that that life is no longer simply biological. Rather, it has an agency that is both geological and molecular. The Anthropocene supplies a vivid presentation of the entanglements - of the naturecultures, of the global hybrids - that are climate change, soil modification, ocean acidification and so on. Yet it is a formulation that would seem to be shadowed by a longing for that which its emergence signals is lost: Man and Nature.

The transition from the Holocene to the Anthropocene can be posed as one in which nature in its geological dimension, which was once assumed (by in large) to be a dense, reliable background to human activity, has now become so saturated by that activity that this nature itself can now explode in catastrophe at any moment (Žižek, In Defence 435) As scientists of the Anthropocene demonstrate,

7 For examples of this thesis see Sachs, Common Wealth and 'Survival'; Friedman. 
human activity has already caused the critical thresholds to a number of the Earth's biogeochemical systems to be crossed. With the possibility of abrupt climate change, ocean anoxic events, and a global mass extinction event, they warn the earth system rests on the edge of chaos (Rockström et al.). ${ }^{8}$ Yet responses to this situation seem to proceed not only as if the distinction between Society and Nature persists, but as if it is this division that must be preserved if calamity is to be averted.

This, it might be contended, has produced two broad strategies of purification by which humanity might be relieved of the Anthropocene's monstrous hybridity. On the one hand, the romantic retreat. This demands that we must leave the nonhumans alone; we've gone too far, we must withdraw - if we are to 'return to safety' and avoid the wrath of James Lovelock's Gaia (see Latour, 'Will Non-Humans?'). On the other, enlightened administration. This asserts Man's sovereignty over Nature and recalls notions of human mastery central to the epistemological and political imaginaries of the Enlightenment. This position is exemplified by Paul Crutzen and Eugene Stoermer, instigators of the term Anthropocene, when they appeal for the 'wise application of knowledge ... to guide mankind towards global, sustainable, environmental management' (Crutzen and Stoermer). This is a position strikingly encapsulated in the title of Mark Lynas's recent book, God Species.

However, the Anthropocene designates a predicament in which the distinction on which such strategies rest has lost its purchase. Neither the prospect of the abyss nor the progress of reason can compel the restitution of environmental order. Both would seem to misunderstand their object. For in one sense the catastrophe has already happened: Nature has ended, Man is dead. This is so in that the opposition which would define the human against the natural world is redundant in a context in which the human is now irrevocably folded into the Earth's systems. Here it would seem the Anthropocene is but the ultimate confirmation of Raymond Williams' observation made decades ago: in 'this actual world there is ... not much point in counterposing or restating the great abstractions of Man and Nature' (83); for, as he continues, 'We have mixed our labour with the earth, our forces with its forces too deeply to be able to draw back and separate either out' (83). More recently climatologist Mike Hulme made the point thus with regard to global warming: 'It is as irrelevant as it is impossible to find the invisible fault line between natural and artificial climate' ('Cosmpolitan Climate' 270). In another sense, to persist as if we live before this catastrophe is to be nostalgic in the full meaning of that word. It is to express

8 Of the nine planetary boundaries established three have already been crossed, those of climate change, rate of biodiversity loss and the nitrogen cycle (See Rockström et al.). 
a longing for that which never was. For the distinction between the social and natural worlds, as Latour, Haraway and others have long made clear, was always already a modern conceit.

\section{V.}

The Anthropocene hails Earthlings: There is an 'element of indecision' that would seem to be contained in the notion of the Anthropocene. As Bronislaw Szerszynski succinctly puts it, 'is this the epoch of the apotheosis, or of the erasure, of the human as the master and end of nature?' (16). This ambivalence would seem to be a condition for the bifurcation between mastery and retreat: between calls to proceed with the assurance of the God species' faith in modernization and its emancipatory promise, and calls to retreat in the wake of modernity's broken pledges and unintended consequences (cf., for example, Lovelock's call for a new Dunkirk in the War on Gaia (150)). However underpinning both promises for omnipresent mastery and pleas for retreat in the face of a vengeful Goddess is a commitment to detachment. That is, through mastery or retreat such proposals would seek to free humans from the obligations, or from the consequences, that the limits of Nature would impose on them. With god-like powers or retreating from godly powers, humans, it seems, are to detach themselves from Nature, from Earth: disciplining it into their obedient servant, or fleeing from its punishment, as if it were an avenging angel.

Latour has contrasted two grand narratives of modernity: freedom and attachment. The first is derived from the modern conception of the separation of Nature and Society, where human mastery over nature, via the intermediary of modern science and technology, is conceived as the advance toward greater emancipation. The second narrative, attachment, posits that science, technology, markets and so on 'have amplified, for at least the last two centuries, not only the scale at which humans and nonhumans are connecting with one another in larger and larger assemblies, but also the intimacy with which such connections are made' (Latour, 'It's Development' 5). All the while convinced by the narrative of modernization and emancipation, moderns 'rendered more and more explicit the fragility of the life support systems that make ... [their] "spheres of existence" possible' (Latour, 'It's Development' 3).

The Anthropocene is nothing if not 'the ultimate learning experience' of the fragility of the systems on which such spheres depend (Latour, 'It's Development' 39); where the 'tight coupling' of human and earth systems render the air, sea, soil and DNA no longer matters of fact, but matters of concern. With a growing awareness of the proliferation of such hybrid naturecultures, Latour 
contends, we have 'shifted to another period' away from one of modernization and emancipation to 'one of explicitation and of attachment' (Latour, 'It's Development' 3 ; italics in original). ${ }^{9}$

To name the subject of this new narrative, which is no longer one of mastery or retreat, but one of attachment, dependency and responsibility, Latour has turned to the terminology of science fiction. With nowhere else to go, it is 'Earthlings' who must live on this planet, without the promise of progress, but with the prospect of progressive change by which a world in common can come to be composed. It is in this sense, then, that the Anthropocene comes to hail neither the God species nor Gaia's assailants, but Earthlings.

\section{VI.}

The Anthropocene - an emerging apparatus: The development of earth system science and its corollary, earth system governance, comes to posit its target, the Anthropocene, in an empirics and an informatics that establishes it at once as an autonomous object of knowledge - 'a single earth system'; and, as a field of intervention, through which 'the co-evolution of human and natural systems' are to be managed 'in a way that secures the sustainable development of human society' (Biermann 4). ${ }^{10}$ Through this emerging apparatus the Anthropocene is subject to two intimately connected processes: its financialization and its augmentation.

Much of the intellectual labour invested in earth system science prepares the planet's ecological systems for the market; supplying an informatics by which they are to be established as various stocks and services integral to the global economy. As Timothy Luke writes: 'Earth System Science aspires to scan and appraise the most productive use of ... [the] resourcified flows of energy, information, and matter as well as the sinks, dumps, and wastelands for all the by-

9 'Explicitation' is a term that Latour borrows from Peter Sloterdijk.

10 The most developed of these is the proposal for earth system governance. See <http://www. earthsystemgovernance.org $>$. This seeks to articulate the knowledge of earth system science into a global administrative regime that offers 'global stewardship and strategies for Earth System management'. This project was inaugurated with the Declaration on Global Change (2001) (see < http://www.essp.org/index. php?id=4l>). In 2001 four bodies of the international scientific community investigating processes of 'global change' convened in Amsterdam. There, representatives of the Geosphere-Biosphere Programme (IGBP), the International Human Dimensions Programme on Global Environmental Change (IHDP), the World Climate Research Programme (WCRP) and the International Biodiversity Programme (Diversitas) adopted the Declaration (see Steffen et al.). The Declaration contended: 'Basic goods and services supplied by the planetary life support system, such as food, water, clean air and an environment conducive to human health, are being affected increasingly by global change. ... The global change programmes are committed to working closely with other sectors of society and across all nations and cultures to meet the challenge of a changing Earth ... [and to establish] deliberate strategies of good management that sustain the Earth's environment while meeting social and economic development objectives'. 
products that commercial products leave behind' ('Developing' 133). Ecological flows thus come to be discursively framed and institutionally managed as the 'terrestrial infrastructure for global capital' (Luke, 'Eco-Managerialism' 106). No longer an externality of the modern industrial economy; ${ }^{11}$ rather, via this environmental accountancy the ecological is to be folded into market relations. Integral here are the risk technologies of finance capital. Futures, derivatives, hedge funds, reinsurance instruments and so on come to figure the contingencies of ecological circulation as an opportunity for profit, commodifying its risk into an abstract universal form to be traded (see LiPuma and Lee; Bryan and Rafferty). Through catastrophe bonds, weather derivatives and other financial instruments advanced by the World Bank, IMF and the secondary insurance industry, $^{12}$ the ecological contingencies that unevenly threaten capital's infrastructure are decoded as such, and recoded as financial risk, which, in turn, is distributed across global capital markets (Cooper 'Economies'; Pryke). ${ }^{13}$ The emerging apparatus of the Anthropocene signals an increasingly thorough folding of ecology and economy, to which the financialization of the earth system is central.

Initiatives seeking the modification of the circulation of biophysical materials of compounds and codes - within the earth system have been signalled as a 'strategic issue' in a report on earth system governance. It asks, 'what are the options and caveats for technological fixes like geo-engineering and genetic modification' for managing the earth system? (GAIM 1, cited in Lövbrand et al. 11). This formally puts questions of terraforming and areoforming on the table as modalities for augmenting life in the Anthropocene: ${ }^{14}$ as potential strategies for reducing the vulnerabilities and enhancing the capacities of the global species-body through engineering the planet's physical systems, so as, for example, 'to "optimize" climate' (by injecting the planet's atmosphere with solar deflecting aerosols) (Crutzen); or through engineering its biochemistry so as to design forms of life that can 'survive and thrive' in the new ecologies of the Anthropocene (Nordhaus and Shellenberger 253). The case for the former has most recently been put forward by a report published by the Royal Society, Geo-Engineering: Giving us time to act? (2009). This argues that international scientific and policy communities need to be prepared for the possibility that geo-engineering will be the pre-emption necessary to complement global change strategies of mitigation and adaptation. ${ }^{15}$ In terms of the latter, the

11 Cf., for example, Stern's contention that climate change represents historically, the most significant 'market failure' - one demanding rapid correction if catastrophic tipping points are to be averted.

12 See, for examples, 'News release: World's first humanitarian insurance policy issued' and 'Caribbean Catastrophe Risk Insurance Facility'.

13 These sentences draw on Dibley and Neilson (148-149).

14 On the beginnings of these terms in works of science fiction see Murphy.

15 As one pundit put it, geo-engineering it would seem is 'a bad idea whose time has come'. See 'Geoengineering'. See also Kintisch. On geo-engineering and the politics of pre-emption see Cooper, 'Pre-empting'. 
bioengineering of 'plants to survive desertification, altered climate zones, and changes in rainfall patterns' is underway (Murphy 56). However, it is with synthetic biology, where proposed designer bacteria will release global modernity from its ecological predicament, that the extravagant promise of the tech fix lies; that is, with the invention of new organisms that will siphon vast volumes of carbon dioxide from the atmosphere or will generate enormous amounts of 'green energy'. ${ }^{16}$ 'We are going to start domesticating bacteria to process stuff inside enclosed reactors to produce energy in a far more clean and efficient manner.' We are, genomic futurist Juan Enriquez continues, at 'the beginning stage of being able to program life' (cited in Specter). This is the domain famously associated with the venture capitalist, Craig Venter.

The emerging apparatus of the Anthropocene, then, signals a mutation in life: no longer simply biological, life is now both geological and molecular. Concomitantly, it is along these dimensions that life itself becomes increasingly subsumed by capital in the thoroughgoing privatization of the shared elements of our species-being. Such a world, in which the geo- and bio-engineered augmentations of life are directed by the rule of capital, is one destined to be increasingly divided, as Mike Davis ('Living') warns, between the 'Earth's firstclass passengers' ensconced in 'green and gated oases' and the dwellers of the ever burgeoning slums of the planet's mega cities. ${ }^{17}$

\section{VII.}

Life in the Anthropocene has no future; it has prospects: Elaborating his Compositionist Manifesto in a curious piece of theory as theatre, Latour has recently re-enacted the flight of the Angelus Novus that Benjamin famously immortalized. ${ }^{18}$ It is a performance with a twist.

Standing before his audience, eyes staring, arms outstretched, his back to the future, Latour dramatises our present moment as one in which the Angel, turning from the wreckage that the storm of progress piles in front of his feet, looks over his shoulder. With a dawning sense of realization he sees that it is his flight

\footnotetext{
16 It is estimated that it requires between fifteen and eighteen terawatts of energy to power the planet per annum. Projections for energy manufactured with the tools of synthetic biology have been estimated to have the potential to produce up to ninety terawatts. As one researcher put it, 'we are talking about producing five times the energy we need on this planet and doing it in an environmentally benign way' (Specter).

17 This is the 'new apartheid' that Žižek (In Defence 428) provocatively formalizes as global capital's key antagonism: that between the 'Included and Excluded'. See too Urry's dystopic image of the unfolding ecological crisis in which the globe's population is split between the poor, who are ruled by 'regional warlordism', and the rich, who are governed by 'digital panopticism'. Davis ('Who Will?') has recently turned to the utopian promise of the city as the site for redressing the environmental crisis.

18 See 'Bruno Latour: 'May Nature Be Recomposed? A Few Questions of Cosmopolitics': <http://www. youtube.com/watch?v=Ie-_erFVz5A $>$. The text for this presentation is drawn from Latour, An Attempt.
} 
from the horror of the past that is the source not only of the destruction, but of the impending calamity - the ecological crisis. In reorienting this gaze, which he transposes as no longer that of the Angel, but that of altogether less ethereal creatures - we Earthlings - Latour suggests the emergence of a new relation to the future. This is, in fact, no future at all. At least, not as it was imagined by the moderns - as revolution, as utopia, as so much 'hype', as he puts it (An Attempt 13). Rather, it is one of the prospect, not that of Progress, but of 'the shape of things to come' (13). This orientation stands not as a 'war cry' of the vanguard of the moderns 'to go even further and faster ahead'; but rather, as Latour continues, 'as a warning, a call to attention, so as to stop going further in the same way as before toward the future' (3). It is here that Latour inserts his call for the slow work of composition; of composing, of building a common world between the humans and the nonhumans that he calls cosmopolitics.

Despite the distance that Latour puts between his position and that of the moderns, it is in this commitment to the common that he acknowledges a shared concern in his manifesto with that of Marx's and Engel's 1848 document. However, he parts company with the earlier texts inasmuch as its politics remain exclusively the domain of the human:

compared to the total transformation of our landscape, cities, factories, transportation systems for which we will have to gird ourselves ... [how] ridiculously timid does Karl Marx's preoccupation with the mere 'appropriation of means of production' seem, when compared against the total metamorphosis of the entire means of production necessary to soon adjust nine billion people on a livable planet Earth? Every product, every biological species, every packaging, every consumer in excruciating detail is concerned in this, together with every river, every glacier, and every bug. (Latour, 'It's Development' 9).

Estranged from their own practices, moderns have ignored such entanglements in their rush to the Future. We are now only beginning to grasp the magnitude of the ruinous consequences of this flight. If to break with its trajectory necessitates the metamorphosis of our entire means of production, this is so because we need different relations to the folding of the human and the nonhuman that capital has historically committed us to, and that have been misrepresented in the abstractions of Humanity and Nature. While the history of capital corresponds to an ever-increasing enmeshing of human and nonhuman entities at scales both planetary and molecular, the bid for human freedom - which is its promise - is one without care for these entanglements. Inasmuch as it presents a thoroughgoing acknowledgment of the inescapability of these relations, the notion of the Anthropocene brings the folding of the human into the air, into the sea, the soil and DNA to the fore as matters of concern. This at least is the lesson of the geological predicament that the moderns bequeath to us. It is a 
permanent lesson. The Anthropocene is here to stay. There can be no return to the Holocene. There is no going 'back to safety'. We cannot save Nature or humanity, 'as it is, or was, or is supposed to have once been' (Dyer-Witheford 7). It is in this sense then, that life in the Anthropocene has no Future. There 'can be no return to earth'; only the prospect of 'recaptur[ing] the strange planet to which capital has abducted us' (7). This, however, is not to be free at last. But dependent, attached, responsible.

Ben Dibley is a researcher and writer based in Sydney, currently working as a research associate at the Centre for Cultural Research, the University of Western Sydney. He has recent publications in the International Journal of Cultural Studies, Cultural Studies Review and New Formations.

\section{Acknowledgements}

The author would like to thank the anonymous referees for their insightful comments from which this version of the paper has considerably benefited. For its remaining inadequacies he alone bears responsibility.

\section{Works Cited}

Benjamin, Walter. 'Theses on the Philosophy of History.' Trans. Harry Zohn. Illuminations. New York: Schocken Books, 1969. 253-264.

Biermann, Frank. 'Earth system governance as a cross cutting theme of global change research.' Global Environmental Change 17 (2007): 4.

Boykoff, Maxwell T. 'Media representational practices in the Anthropocene Era.' Uncertainties in Environmental Modelling and Consequences for Policy Making. Ed. Philippe Baveye, Jaroslav Mysiak and Magdeline Laba. Dordrecht: Springer, 2009. 339-350.

Bryan, Dick and Michael Rafferty. Capitalism with Derivatives: A Political Economy of Financial Derivatives, Capitalism and Class. London: Palgrave, 2006.

'Caribbean Catastrophe Risk Insurance Facility.' < http://web.worldbank.org/ WBSITE/EXTERNAL/COUNTRIES/LACEXT/0, , contentMDK:20939758 pag ePK:146736 piPK:146830 theSitePK:25855>. Accessed 19 February 2009. 
Chakrabarty, Dipesh. 'Brute force.' Eurozine, 7 October 2010. <http://www. eurozine.com/articles/2010-10-07-chakrabarty-en.html>. Accessed 10 October 2010.

—. 'The Climate of History: Four Theses.' Critical Inquiry 35 (2009): 197-222.

Cooper, Melinda. 'Economies of Turbulence: Climate Change and the Market for Weather Derivatives.' Theory, Culture \& Society 27.2-3 (2010):167-190.

-. 'Pre-empting Emergence: the Biological Turn in the War on Terror.' Theory, Culture \& Society 23.4 (2006): 113-135.

Crist, Eileen. 'Beyond the Climate Crisis: A Critique of Climate Change Discourse.' Telos 141 (2007): 29-55.

Crutzen, Paul. 'Albedo Enhancement by Stratospheric Sulphur Injections: a contribution to revolve a policy dilemma?' Climate Change 77 (2006): 211219.

-, and Eugene Stoermer. IGBP Newsletter 41, May 2000. <http://www.mpchmainz.mpg.de/ air/anthropocene/Text.html>. Accessed 6 January 2008.

Dalby, Simon. 'Anthropocene Geopolitics: Globalisation, Empire, Environment and Critique.' Geography Compass 1.1 (2007): 103-118.

Davis, Mike. 'Living on the Ice Shelf: Humanity's Meltdown.' Tomdispatch, 26 June 2008. <http://www.tomdispatch.com/post/174949/mike_davis_ welcome_to_the_next_epoch>. Accessed 3 February 2009.

—. 'Who Will Build the Ark?' New Left Review 61 (2010): 29-46.

Dibley, Ben and Neilson, Brett. 'Climate Crisis and the Actuarial Imaginary: "The War on Global Warming".' New Formations 69 (2010): 144-159.

Dillon, Michael and Luis Lobo-Guerrero. 'The Biopolitical Imaginary of Speciesbeing.' Theory, Culture \& Society 26.1 (2009): 1-23.

Dyer-Witheford, Nick. 'Twenty-First Century Species-Being'. Presented at the Sixth Annual Marx and Philosophy Conference, Institute of Education, University of London, 6 June 2009.

Friedman, Thomas. Hot, Flat, and Crowded: Why we need a green revolution and how it can renew America. New York: Farrar, Straus and Giroux, 2008.

GAIM. 'Hibertiam Questions.' GAIM Newsletter 5 (2002): 1. 
'Geo-engineering: "A Bad Idea Whose Time Has Come".' NPR, 29 May 2010. $<$ http://www.npr.org/templates/story/story.php?storyId =127245606>. Accessed 24 June 2010.

Geo-Engineering: Giving us time to act? London: The Institute of Mechanical Engineers, Royal Society, 2009.

Gibson-Graham, J. K. and Gerda Roelvink. 'An Economic Ethics for the Anthropocene.' Antipodes 41 (2009): 320-346.

Hodson, Mike and Marvin, Simon. 'Urbanism in the Anthropocene: Ecological urbanism or premium ecological enclaves?' City 14.3 (2010): 298-313.

Hulme, Mike. 'Cosmopolitan Climates: Hybridity, Foresight and Meaning.' Theory, Culture \& Society 27.2-3 (2010): 267-276.

- Why We Disagree about Climate Change: Understanding Controversy, Inaction and Opportunity. Cambridge: Cambridge UP, 2009.

Kintisch, Eli. Hack the Planet: Science's Best Hope, or Worst Nightmare, for Averting Climate Catastrophe. New Jersey: Wiley, 2010.

Latour, Bruno. An Attempt at Writing a 'Compositionist Manifesto'. 2010. $<$ http://www.bruno-latour.fr/articles/article/120-COMPO-MANIFESTO. pdf $>$. Accessed 17 August 2010.

-. 'Is Re-modernization Occurring - And If So, How to Prove It? A Commentary on Ulrich Beck.' Theory Culture Society 20.2 (2003): 35-48.

—. "'It's development, stupid!" or: How to Modernize Modernization.' In Postenvironmentalism. Ed. Jim Proctor. Cambridge, MA: MIT Press, 2007.

- 'Love Your Monsters: why we must care for our technologies as we do our children.' In Love Your Monsters: Postenvironmentalism and the Anthropocene. Ed. M. Shellenberger and T. Nordhaus. Oakland: The Breakthrough Institute, 2011.

- A Plea for Earthly Sciences. Keynote lecture for the annual meeting of the British Sociological Association, East London, April 2007. <http://www. bruno-latour.fr/sites/default/files/102-BSA-GB_0.pdf > . Accessed 15 January 2010.

- 'Will non-humans be saved? An argument in ecotheology.' Journal of the Royal Anthropological Institute 15 (2009): 459-475.

LiPuma, Edward and Benjamin Lee. Financial Derivatives and the Globalisation of Risk. Durham: Duke UP, 2004. 
Lövbrand, Eva, Johannes Stripple and Bo Wimand. 'Earth System Governmentality: Reflections on science in the Anthropocene.' Global Environmental Change 19.1 (2009): 7-13.

Lovelock, James. The Revenge of Gaia: Earth's Climate Crisis and the Fate of Humanity. New York: Basic Books, 2006.

Luke, Timothy. 'Developing Planetarian Accountancy: Fabricating Nature as Stock, Service, and System or Green Governmentality.' Current Perspectives in Social Theory 26 (2009): 129-159.

-. 'Eco-Managerialism: environmental studies as a power/knowledge formation'. In Living with Nature: environmental politics as cultural discourse. Ed. Frank Fisher and Maarten Hajer. Oxford: Oxford UP, 1999. 103-120.

Lynas, Mark. The God Species: How the Planet Can Survive the Age of Humans, London: Fourth Estate, 2011.

Murphy, Patrick. 'Engineering Planets, Engineering Ourselves: The Ethics of Terraforming and Areofroming in an Age of Climate Change.' Journal of Ecocriticism 1.1 (2009): 54-59. <http://ojs.unbc.ca/index.php/joe/index>. Accessed 6 January 2010.

'News release: World's first humanitarian insurance policy issued.' < http://www. axa.com/lib/axa/uploads/cpsocietes/2006/United_nations_PR_20060306. pdf $>$. Accessed 19 February 2009.

Nordhaus, Ted and Michael Shellenberger. Break Through: From the Death of Environmentalism to the Politics of Possibility. New York: Houghton Mifflin, 2007.

Pryke, Michael. 'Geomoney: an option on frost, going long on clouds'. Geoforum 38.3 (2007): 576-588.

Rigby, Kate. 'Writing in the Anthropocene: Idle Chatter or Ecoprophetic Witness?' Australian Humanities Review 47 (2009). <http://www. australianhumanitiesreview.org/archive/Issue-November 2009/rigby.html>. Accessed 2 March 2011.

Robin, Libby and Steffen, Will. 'History for the Anthropocene.' History Compass 5.5 (2007): 1694-1719.

Rockström, Johan et al. 'A safe operating space for humanity.' Nature 461 (2009): 472-5. <http://www.nature.com/nature/journal/v461/n7263/full/461472a. html $>$. Accessed 2 March 2010. 
Sachs, Jeffery. Common Wealth: Economics for a Crowded Planet. New York: Penguin, 2008.

-. 'Survival in the Anthropocene.' BBC Reith Lectures 2007, 3 September 2007. <http://www.bbc.co.uk/radio4/reith2007/lecture2.shtml>. Accessed 4 October 2009

Shellenberger, Michael and Ted Nordhaus, eds. Love Your Monsters: Postenvironmentalism and the Anthropocene. Oakland: The Breakthrough Institute, 2011.

Sigmundsson, Freysteinn et al. 'Climate effects on volcanism: influence on magmatic systems of loading and unloading from ice mass variations, with examples from Iceland.' Philosophical Transactions of the Royal Society A 368 (2010): 2519-2534.

Specter, Michael. 'A Life of Its Own: Where will synthetic biology lead us?' The New Yorker, 28 September 2009. 56-64. <http:/www.newyorker.com/ reporting/2009/09/28/090928fa_fact_specter?currentPage $=a>$. Accessed January 6, 2010.

Steffen, Will, Paul Crutzen and John McNeill. 'The Anthropocene: Are humans now overwhelming the great forces of nature?' Ambio 36.8 (2007): 614-621.

Stern, Nicholas. The Stern Review: The Economics of Climate Change, 2006. <http://webarchive.nationalarchives.gov.uk/+/http://www.hm-treasury. gov.uk/stern_review_report.htm>. Accessed 22 October 2010.

Szerszynski, Bronislaw. 'Reading and Writing the Weather: Climate Technics and the Moment of Responsibility.' Theory, Culture \& Society 27.2-3 (2010): 9-30.

Urry, John. 'Climate change, Travel and Complex Futures.' The British Journal of Sociology, 59.2 (2008): 261-279.

Williams, Raymond. 'Ideas of Nature.' In Problems in Materialism and Culture: selected essays. London: Verso, 1980. 67-85.

Zalasiewicz, Jan. et al. 'Are We Now Living in the Anthropocene?' GSA Today 18.2 (2008): 4-8.

-. 'The New World of the Anthropocene.' Environmental Science \& Technology 44.7 (2010): 2228-2231.

Žižek, Slavoj. In Defence of Lost Causes. London: Verso, 2008.

- Living in the End Times. London: Verso, 2010. 